Published in final edited form as:

Vet Immunol Immunopathol. 2008 May 15; 123(1-2): 3-13.

\title{
Molecular Mechanisms of FIV Infection
}

\author{
John H. Elder ${ }^{1,}{ }^{\star}$, Magnus Sundstrom ${ }^{1}$, Sohela de Rozieres ${ }^{2}$, Aymeric de Parseval ${ }^{3}$, Chris K. \\ Grant ${ }^{4}$, and Ying-Chuan Lin ${ }^{1}$ \\ 1 Department of Molecular Biology, The Scripps Research Institute, 10550 North Torrey Pines Road, La \\ Jolla, CA 92037
}

2 Biomatrica, 5627 Oberlin Drive, Suite 124, San Diego, CA 92121

3 The Public Health Research Institute, 225 Warren Street, Newark, NJ 07103

4 Custom Monoclonals International, 813 Harbor Blvd. \#284, W. Sacramento, CA 95691

\begin{abstract}
Feline immunodeficiency virus (FIV) is an important viral pathogen worldwide in the domestic cat, which is the smallest animal model for the study of natural lentivirus infection. Thus, understanding the molecular mechanisms by which FIV carries out its life cycle and causes an acquired immune deficiency syndrome (AIDS) in the cat is of high priority. FIV has an overall genome size similar to HIV, the causative agent of AIDS in man, and shares with the human virus genomic features that may serve as common targets for development of broad-based intervention strategies. Specific targets include enzymes encoded by the two lentiviruses, such as protease (PR), reverse transcriptase (RT), RNAse H, and integrase (IN). In addition, both FIV and HIV encode Vif and Rev elements essential for virus replication and also share the use of the chemokine receptor CXCR4 for entry into the host cell. The following review is a brief overview of the current state of characterization of the feline/ FIV model and development of its use for generation and testing of anti-viral agents.
\end{abstract}

\section{Keywords}

feline immunodefiency virus; receptor; CD134; CXCR4

\section{Introduction}

FIV Pathology

FIV is a lentivirus associated with an AIDS-like syndrome in the domestic cat (Pedersen, 1993). Like HIV, FIV can be transmitted via mucosal exposure, blood transfer, and vertically via prenatal and postnatal routes (Pedersen, 1987; Rideout, 1992; O'Neil, 1995; O’Neil, 1996; Obert, 2000;). Progression of the disease follows a pattern typical of that observed with primate lentiviruses, starting with a relatively short (weeks) acute phase denoted by increasing viral loads, febrile episodes, weight loss, lymphadenopathy, and neutropenia. The acute phase

\footnotetext{
*Author to whom correspondence should be addressed: Department of Molecular Biology, The Scripps Research Institute, 10550 N. Torrey Pines Road, MB14, La Jolla, CA 92037 USA. Email: jelder@ scripps.edu, phone: 858-784-8270, FAX: 858-784-2750.

Conflict of Interest Statement

None of the authors has a financial or personal relationship with other people or organisations that could inappropriately influence or bias the paper entitled "Molecular Mechanisms of FIV Infection".

Publisher's Disclaimer: This is a PDF file of an unedited manuscript that has been accepted for publication. As a service to our customers we are providing this early version of the manuscript. The manuscript will undergo copyediting, typesetting, and review of the resulting proof before it is published in its final citable form. Please note that during the production process errors may be discovered which could affect the content, and all legal disclaimers that apply to the journal pertain.
} 
is followed by an of t-protracted (years) asymptomatic phase denoted by relatively strong antiviral immune responses, lower viral titers, a gradual decline in $\mathrm{CD} 4^{+}$cells, and minimal clinical symptoms. The terminal phase is marked by immunologic decompensation, exacerbation of plasma viral load, and clinical symptoms of immunodeficiency with opportunistic infections (Pedersen, 1993; English, 1994). Lymphoid tissue alterations are consistent with those in HIV and SIV infections and include thymic depletion, lymphoid hyperplasia, plasmacytosis, and terminal lymphoid depletion (Callanan, 1993; Bach, 1994; Beebe, 1994; English, 1994; Parodi, 1994; Woo, 1997; Rogers, 1998). Neurological manifestations are also evident (Lafrado, 1993; Phillips, 1994; Prospero-Garcia, 1994; Phillips, 1996) including delayed auditory evoked and visual evoked potential changes (Lafrado, 1993; Phillips, 1994) and marked alterations in sleep patterns (Prospero-Garcia, 1994a). Many of these early symptoms resolve as the animals proceed into the latent phase of the disease, although the neurological abnormalities persist. As the disease progresses, decline in the number of $\mathrm{CD}^{+} \mathrm{T}$ cells continues, with ultimate increase in viral load in the later stages of the disease (O'Neil, 1996; Obert, 2000). Animals, if not euthanized, generally die of opportunistic infections.

Considerable advances have been made in understanding the molecular workings of FIV since its discovery 20 years ago, both from the standpoint of understanding the rudiments of the virus life cycle as well as in establishing the molecular basis for the observed pathogenic phenotypes outlined above. Although FIV is of direct concern to veterinary medicine, the majority of the work has involved comparison to HIV, with the hope that the cat model can contribute to the development of intervention strategies effective against both lentivirus infections. As will be shown below, many parallels exist in both the pathology and molecular structure of FIV and HIV and substantial progress has been made in use of the cat model for development of both drug and vaccine treatments.

\section{FIV Genomic Structure}

The overall genomic structure of FIV is markedly similar to HIV, although there are important distinctions (Olmsted, 1989; Talbott, 1989; Phillips, 1990) (Figure 1). The length of the FIV genome is around 9400 nucleotides, approximating that of HIV and other lentiviruses. The integrated provirus is bordered by long terminal repeats (LTRs) and possesses gag, pol, and env genes as all other retroviruses. As with other lentiviruses, FIV uses a RRNA $_{\text {Lys }}$ primer binding site to prime first strand synthesis by reverse transcriptase (RT). Transport of unspliced and singly spliced mRNAs is regulated by Rev interaction with the distinction that Rev Response Element (RRE) and second coding exon of Rev are located 3' of env instead of overlapping it as in primate lentiviruses (Phillips, 1992). FIV lacks Vpr, Vpu, and Nef "accessory" genes that are present in HIV. FIV has an apparent transactivator, termed OrfA (or Orf2), which promotes a net increase in translation of gene products whose transcription is driven by the FIV LTR (Sparger, 1992; Waters, 1996; de Parseval, 1999). However, OrfA does not act via a TAR element, as is the case with HIV-1 Tat and promotes transcription/ translation via mechanisms distinct from that of other lentiviruses (Chatterji, 2002). Sparger's laboratory has presented evidence that there is no wholesale increase in transcription in the presence of Orf $\mathrm{A}$ and thus, the increase in net translation may be the consequence of downstream action (Gemeniano, 2003, 2004). They also showed that OrfA may have relatedness to $\mathrm{Vpr}$ and present indications of involvement in virus release from the cell and influence on cell cycle, similar to HIV Vpr (Gemeniano, 2003). Overall, the findings suggest that OrfA may be a multi-functional protein, which would certainly be in keeping with the need for versatility of gene products encoded by a relatively small viral genome.

Typical of most other lentiviruses, the Gag polyprotein is expressed via ribosomal frameshifting (Morikawa, 1992) and is comprised of a myristoylated matrix (MA) protein, a capsid 
(CA) protein, and a nucleocapsid (NC) protein that has two copies of the zinc finger motif (Elder, 1992) (Figure 1). FIV lacks a P6 protein between Gag and Pol, but contains instead a P2 protein (Elder, 1993) that has a P(S/T)AP domain necessary for virus budding (Manrique, 2004). Thus, it is likely that $P 2$ serves the same purpose as HIV-1 P6. It is now recognized that the PTAP domain in HIV P6 recruits TSG 101, a cellular protein involved in the virus budding process (Garrus, 2001; Martin-Serrano, 2001; VerPlank, 2001; Demirov, 2002; Freed, 2002). As to whether similar interactions are critical for FIV budding remains to be determined, but this appears likely. The FIV Pol polyprotein is comprised of protease (PR), reverse transcriptase (RT), and integrase (IN) genes, but in addition contains a gene encoding deoxyuridine pyrophosphatase (DU) between RT and IN (Elder, 1993; Lerner, 1995) (Figure 1). FIVs lacking DU are incapable of successful propagation in cells that are not undergoing division, such as primary macrophages, whereas wild type FIV will productively infect such cells (Lerner, 1995). These findings are also true for equine infectious anemia virus (EIAV), which is also a $\mathrm{DU}^{+}$lentivirus (Threadgill, 1993; Steagall, 1995). DU is not necessary for replication in rapidly dividing cells, due to high endogenous levels of DU in the replicating cell (Lerner, 1995). The primary role of DU is to prevent mis-incorporation of uracil into DNA by limiting the concentration of dUTP through conversion to dUMP, a precursor for dTTP synthesis. DU FIV accumulates five- to eight-fold more base changes, primarily G->A transitions, than wild type FIV during replication in macrophages in vivo, consistent with the mis-incorporation of uracil into viral DNA through utilization by RT of undegraded dUTP during viral DNA synthesis. Importantly, when HIV-1 infects non-dividing cells, it must also deal with the problem of uracil misincorporation, although it does not encode DU. Findings of others suggest that Vpr may compensate for the lack of DU in HIV-1, both by its necessity for growth of macrophage-tropic isolates in primary macrophages and by an apparent association with uracil $\mathrm{N}$-glycosylase (Ung), the enzyme responsible for excision of uracil mis-incorporated into DNA (Bouhamdan, 1996). Mutations of Vpr that knock out Ung association causes a phenotype remarkably similar to the DU' ${ }^{-}$phenotype noted in FIV and EIAV (Mansky, 2000).

A gene encoding viral infectivity factor (Vif) is present $3^{\prime}$ of $p o l$, as in other lentiviruses except EIAV. Interestingly, findings indicate that HIV Vif also acts to reduce G->A transition mutations, but by preventing cytidine deamination by the cellular deaminase, APOBEC-3G (Mangeat, 2003; Zhang, 2003). The role of Vif in the FIV life cycle is currently being investigated to determine if parallels exist between Vif function in FIV and HIV.

The env gene encodes heavily glycosylated SU and TM proteins and exhibits considerable amino acid sequence variation, with 5 consensus major variable regions (V1-V5) in SU and 3 (V6-V8) in TM (Phillips, 1990; Pancino, 1993). The mechanism of virus entry dictated by interactions of the FIV envelope with binding and entry receptors closely parallels SU/receptor interactions noted with HIV. Characterization of receptor binding and entry of FIV has progressed markedly in the last few years and may offer an additionally target for development antiviral therapies in both cats and man (see below and also Willett, this issue). Four env subtypes (clades) plus numerous outliers have been defined via Env sequences (Bachmann, 1997). The genetic-clade variation of FIV is remarkably similar to that found in HIV (Delwart, 1997), although the bias towards non-synonymous site changes is not as great, especially for the B clade (Bachmann, 1997; Delwart, 1997). As with HIV, heteroduplex mobility assay has been used to define the diversity of FIV envelope sequence subtypes, as well as assist in the identification of numerous inter-subtype recombinants. Evolutionary trends, as assessed by rates of synonymous and non-synonymous base changes and level of mutational saturation, differ between the most commonly found FIV env clades, A and B (Sodora, 1994, 1995). FIV is tropic for T cells (Pedersen, 1987; Yamamoto, 1988; Sparger, 1989; Novotney, 1990; Brown, 1991; Beebe, 1994) macrophages (Brunner, 1989; Rideout, 1992; Callanan, 1993; Parodi, 1994), and central nervous system (CNS) cells. In vivo tissue tropism studies have demonstrated viral RNA in T cells, macrophages, and CNS cells. FIV RNA has also been 
demonstrated in association with follicular dendritic cells (FDC) (Toyosaki, 1993; Bach, 1994; Hurtrel, 1994). Although CD4 ${ }^{+}$cell decline is a hallmark of FIV infection, FIV has a broader lymphocyte tropism than $\mathrm{CD} 4^{+} \mathrm{T}$ cells, with infection also evident in at least a subset of $\mathrm{CD}^{+}$T cells and B cells in vitro and in vivo (Brown, 1991; Willett, 1993; de Parseval, 2000).

In spite of the targeting of $\mathrm{CD} 4{ }^{+}$cells, $\mathrm{CD} 4$ is not used as a binding receptor for FIV. However, all domestic cat FIVs examined to date bind and utilize the chemokine receptor, CXCR4 as an entry receptor (Poeschla, 1998; Willett, 1998) similar to T celltropic HIVs. Recent studies (de Parseval, 2001; Joshi, 2005) have indicated that FIV infection of certain cells may occur solely mediated via CXCR4 if expression of the chemokine receptor is sufficiently high. However, feline $\mathrm{CD}^{+} \mathrm{T}$ cells express a $43 \mathrm{kDa}$ glycoprotein that past studies had demonstrated is a binding receptor for FIV SU (de Parseval, 1999). Studies of Shimojima et al (Shimojima, 2004) have now shown that this molecule is the activation marker, CD134, and we have now confirmed that the SU binding molecule previously reported was, indeed, CD134 (de Parseval, 1999; also see below). The demonstration that CD134 is up-regulated on activated CD4 ${ }^{+} \mathrm{T}$ cells (de Parseval, 2004) explains how FIV targets this cell population in vivo in spite of failure to bind CD4. Furthermore, soluble CD134 can interact with the virus to facilitate productive infection of $\mathrm{CD}_{134^{-}} \mathrm{CXCR}^{+}$target cells (de Parseval, 2005), indicating that the binding receptor alters the conformation of SU to promote high affinity binding to CXCR4 (Figure 2). This parallels findings with CD4 binding to HIV SU and indicates that although different binding receptors are involved, both viruses use very similar mechanisms to infect target cells. Furthermore, neutralizing monoclonal antibodies have been identified that only neutralize the virus when soluble CD134 is present (de Parseval, 2006). Again, these findings parallel observations of such masked neutralizing epitopes on HIV that become available upon interaction of SU with the CD4 binding receptor (Kwong, 2002; Moulard, 2002; Labrijn, 2003; Lusso, 2005; Xiang, 2005). The striking similarity and conservation of entry mechanisms between the two divergent lentiviruses likely is the result of common immunological pressures in the two hosts. Thus, the feline lentivirus offers a valuable venue to study the mechanisms of lentivirus infection of T cells and for development of strategies to compromise the virus' ability to escape immune surveillance.

\section{FIV as a system for development of intervention strategies}

As detailed above, there are many parallels between the outcomes of infection with FIV in the cat and infection of humans by HIV. Additionally, the target cell populations are similar and thus both viruses are confronted with similar obstacles for replication and perpetuation of species. These two lentiviruses have evolved along unique pathways that have led to development of alternative mechanisms to deal with certain aspects of replication, including transcriptional transactivation and uracil misincorporation. However, there are sufficient similarities to make the cat/FIV model a valuable tool for several lines of direct experimentation. The utilization of CXCR4 by FIV as one of the receptors used to enter target cells is an important similarity to HIV that can be explored in development of intervention strategies. The parallels in the role of the binding receptor in facilitating interaction with CXCR4 in the two systems are striking and imply a strong selection for similar mechanisms of entry and evasion of immune surveillance. The Gag and Pol gene products have common functions in the two viruses and in many cases, respond to the same inhibitors. Use of the cat for development of broad-based protease inhibitors has been successful (Lee, 1998, 1999; also see below). Nucleoside analogs that interact with the active site of reverse transcriptase have been found efficacious against both FIV and HIV (North, 1989). Given the high relatedness of integrase proteins in the two lentiviruses, it is likely that FIV will serve as a valuable system for development of anti-integrase drugs. The structural proteins of Gag may also provide broadbased targets, since all lentiviruses share common morphological features. Elements of the 
virus core are likely to maintain commonalities in their mechanisms of action and orientations in the particles. The matrix, capsid, and nucleocapsid proteins may thus present effective targets for broad-based intervention strategies. As pointed out above, the P2 protein of FIV (Elder, 1993) is an apparent functional homologue to the P6 protein of HIV and shares late domain homologies (Demirov, 2002; Freed, 2002). Both HIV and FIV encode Vif proteins, which may provide an additional target for intervention strategies to be used in both lentivirus systems. Importantly, the cat offers an economical, low biohazard, and readily manipulated venue for in vivo testing of potential therapeutic modalities that cannot be economically tested in primate models. Thus, anti-viral approaches, both drug and vaccine treatments (see Yamamoto, this issue), can be carried forward directly into the natural host species.

\section{PR as a target for antiviral therapies}

Much of our laboratory's efforts to develop broad-based antivirals using the cat model have centered around use of PR as a target for drug development and testing. The aspartic protease has the critical responsibility for the processing of viral Gag and Gag-Pol polyproteins into individual structural and enzymatic proteins during assembly and maturation (Pettit, 1991; Elder, 1993; Dunn, 1994; Katz, 1994; Tozser, 1997; Palella, 1998). This proteolytic step is highly specific, ordered, and essential for producing mature and infectious retrovirus particles (Pettit, 1994; Tomasselli, 1994; Swanstrom, 1997; Pettit, 1998). Therefore, PR has been a very important target for antiviral therapies (Vacca, 1997; Swanstrom, 2000). There are several approved protease inhibitors available that are effective for treating HIV-1 infection (Vacca, 1997; Swanstrom, 2000; Richman, 2004; Johnson, 2005). Combination drug therapies have been used successfully in the treatment of AIDS brought on by infection of individuals with HIV-1. In particular, the use of highly specific inhibitors of PR in combination with RT inhibitors, referred to as highly active anti-retroviral therapy (HAART), has proven to suppress HIV-1 replication to undetectable levels in patients (Collier, 1996; Gulick, 1997; Kirk, 1999; Richman, 2004; Johnson, 2005). However, HIV-1 variants frequently evolve that are resistant to these inhibitors (Condra, 1995; Jacobsen, 1996; Molla, 1996; Zhang, 1997; Palella, 1998; Young, 1998; Lawrence, 1999; Kutilek, 2003; Kozal, 2004). As many as $40 \%$ of the patients receiving HAART have a viral rebound within the first 3 years and this number is likely to be higher outside of controlled studies (Cohen, 1998). In addition, transmission of resistant HIV has been observed and is likely to increase with the increase of patients on combination therapy (Cohen, 1998). Also, poor tolerance to current protease inhibitors by a significant number of patients may lead to increased non-compliance, which may be the leading reason for cases of failure of HAART therapy. Side effects resulting from long-term drug treatment have also been observed. Both of the latter problems might be allayed by development of drugs with better bioavailability and length of efficacy per dosage, which would reduce the drug regimen. Thus, there is a need to develop novel inhibitors with activities against drug-resistant isolates that exhibit delayed resistance development and show a high degree of specificity (Kutilek, 2003). Defining the determinants of substrate specificity of the lentiviral PRs is a logical first step in the development of such broad-based inhibitors.

FIV protease, like HIV-1 protease, is a homodimeric aspartic proteinase and the two enzymes are strikingly similar at the crystallographic level, particularly within the substrate binding region (Wlodawer, 1995; Laco, 1997) (Figure 3). However, FIV is distinct in that each monomer is comprised of 116 amino acids, as opposed to 99 amino acids for HIV-1 protease, with only 27 conserved amino acids between FIV and HIV-1 PRs. Like HIV protease, FIV PR is responsible for processing Gag and Gag-Pol polyproteins (Elder, 1993). Similar to SIV and HIV-1 PRs, autoproteolysis of FIV protease is observed in vitro (Laco, 1997). Despite these similarities, FIV PR is specific to its respective substrates and inhibitors of HIV-1 protease currently employed in clinic do not inhibit FIV protease (Slee, 1995; Schnolzer, 1996; Dunn, 1999). FIV protease cleaves the FIV MA/CA cleavage junction efficiently. However, it does 
not appreciably cut the HIV-1 MA/CA cleavage junction, despite the presence of four identical residues in the P3-P3' position. HIV-1 protease prefers its own substrates as well, but can cleave FIV MA/CA cleavage junction to some degree. Important to the present discussion, there are at least 6 mutations found in HIV-1 proteases associated with drug resistances that are identical to structurally equivalent residues of wild type FIV protease (Slee, 1995). Two particularly interesting resistance mutations of HIV-1 protease, Val32 $\rightarrow$ Ile (FIV Ile37) and Ile $50 \rightarrow$ Val (FIV Val59), are located in the substrate binding pockets of the protease (Figure 3), which suggests they may play an important role in the inhibitor and substrate selectivity of retroviral protease. Recent studies (Lee, 1998; Lee, 1999) have shown that a major structural distinction between FIV and HIV-1 PRs is that the combined S1/S3 substrate binding pocket is restricted in size relative to the same site in HIV-1 PR. This finding offers a structural explanation for the failure of the current HIV-1 PR inhibitors, which possess bulky P3 groups, to inhibit FIV PR (Lee, 1998, 939-44). Importantly, many drug-resistant HIV-1 PRs appear to have more restricted $S 1 / \mathrm{S} 3$ subsites as well (Lee, 1999, 1145-1155), reducing inhibitor binding affinities in a manner similar to the feline enzyme. In addition, the nature of S2/S2' amino acids is particularly critical in directing PR substrate specificity as well as certain inhibitor efficacies. Thus, studies directed at understanding the structural basis for inhibitor and substrate specificity in the feline and human systems may lead to development of broad-based inhibitors with efficacy for a range of HIV variants.

Both FIV and HIV-1 PRs recognize, approximately, the P4-P4' residues of peptide substrates via a long cavity in the middle of the protease, as analyzed by biochemical experiments (Moore, 1989; Weber, 1989; Tozser, 1991; Tozser, 1992; Silva, 1996; Tozser, 1997) and crystallographic analyses (Miller, 1989; Erickson, 1990; Swain, 1990). Both homodimeric PRs utilize an acid-base hydrolysis mechanism in which aspartic acids 25 and 25' (of HIV-1 PR; 30 and $30^{\prime}$ for FIV PR) activate a water molecule to perform a nucleophilic attack on the amide carbonyl between the P1 and P1' positions in various peptide substrates (Silva, 1996). Like most aspartic proteases, optimal substrate cleavage occurs at approximately pH 4-5 (Tozser, 1992; Polgar, 1994; Kutilek, 2003). There are three major structurally conserved regions that make up the substrate binding pockets of PR: 1) the active core region (residues 30-38 for FIV; 25-33 for HIV); 2) the flap (residues 54-60 for FIV; 45-51 for HIV); and 3) C-terminal “90's loop" region (residues 98-101 for FIV; “80”s loop” for HIV, residues 80-84) (Figure 3). Within these regions, there are 11 amino acids that differ between FIV and HIV-1 proteases. These residues have proved to be good candidate targets for mutational studies of substrate selectivity. The 11 different amino acid residues in the S4 - S4' subsites of FIV protease; Ile35, Ile37, Gln54, Asn55, Met56, Ile57, Val59, Ile98, Gln99, Pro100 and Leu101, most likely account for the specificity of the substrate/inhibitor binding. The corresponding residues in HIV-1 protease are Asp30, Val32, Lys45, Met46, Ile47, Gly48, Ile50, Pro81, Val82, Asn83 and Ile84, respectively. All the aforementioned residues have now been documented to mutate in response to protease inhibitor treatment (Schinazi, 1997, 129-142; Rhee, 2003, 298-303). We have prepared a series of mutant FIV PRs in which HIV-1 amino acid residues have been substituted into the FIV PR background at equivalent positions (highlighted in Figure 3). Confirmation of the involvement of several of these residues in both substrate and inhibitor specificities has been obtained (Lee, 1998; Lin, 2000, 2003, 2006). These wild type and mutant FIV PRs have, and will continue to serve, as a structural library for further defining substrate specificity and for inhibitor refinement in the proposed research.

\section{Role of Gag-Pol polyprotein structure in processing}

An increasing body of evidence points to a pivotal role of the polyprotein folding/conformation in the temporal cleavage of the Gag- and Gag-Pol proteins that is necessary for generation of infectious virus (Pettit, 1994; Vogt, 1996; Swanstrom, 1997; Wiegers, 1998; Gross, 2000). The studies of Petit et al. (Pettit, 1994; Swanstrom, 1997; Pettit, 1998, 2004, 2005, 2005) pointed 
out that polyprotein cleavage occurs in a specific order and that alteration of the order by sitedirected mutagenesis of certain sites resulted in production of non-infectious HIV. In particular, cleavage at the $\mathrm{N}$-terminus of $\mathrm{NC}$ appeared to be the earliest cleavage event, at least in vitro, and subsequent studies have shown early cleavage on either side of NC (Pettit, 2005; also see below). Differences in the rate of cleavage of synthetic substrates encompassing the cleavage sites suggested that the order of cleavage was in part, dictated by the relative cleavage efficacy of each junction. However, more recent studies have indicated that the availability of sites around NC, based on folding of the polyprotein relative to the "embedded" protease, is likely the critical trigger to the initiation of ordered processing. Interesting studies of Kaplan, Dunn, and colleagues have shown that subtle changes at the $\mathrm{N}$-terminus of the embedded protease can markedly influence polyprotein processing in cis with no apparent influence on the ability of free protease to cleave the polyprotein in trans (Pettit, 2004, 2005). This finding underscores the role of polyprotein conformation in processing and the importance of the temporal cleavage of Gag-Pol in the generation of infectious virus. As recently reported (Lin, 2006), similar events occur during processing of FIV Gag-Pol polyprotein and the data again reinforce the requirements for early cleavage around NC to generate infectious virus. Additional studies are in progress to investigate factors that dictate ordered polyprotein cleavage. Given the critical nature of the proper temporal cleavage of $\mathrm{Gag} / \mathrm{Pol}$ in generating infectious virus, that process offers yet another venue to disrupt the virus life cycle, independent of direct inhibition of PR.

\section{Conclusion}

In summary, great strides have been made in dissecting the inner workings of the FIV genome and in defining the parallels and distinctions between the feline lentivirus and HIV. FIV is sufficiently diverse from HIV so as to allow extensive ex vivo and in vivo work with low biohazard and the cost of maintaining this small animal model is a fraction of that required for non-human primate models. Of particular importance, FIV and HIV share many features in their life cycles, host cell targets, and protein functions so as to make the cat a particularly valuable system for developing antiviral therapies at several levels.

\section{Acknowledgements}

Work summarized in this review was supported from grants R01AI025825 and R01 AI040882 of the National Institute of Allergy and Infectious Diseases of the National Institutes of Health. We thank Ms. Karen Tam for technical assistance and Ms. Nancy Dorman for manuscript preparation.

\section{References}

Bach JM, Hurtrel M, Chakrabarti L, Ganiere JP, Montagnier L, Hurtrel B. Early stages of feline immunodeficiency virus infection in lymph nodes and spleen. AIDS Res Hum Retrovir 1994;10:17318. [PubMed: 7888233]

Bachmann MH, Mathiason-Dubard C, Learn GH, Rodrigo AG, Sodora DL, Mazzetti P, Hoover EA, Mullins JI. Genetic diversity of feline immunodeficiency virus: dual infection, recombination, and distinct evolutionary rates among envelope sequence clades. J Virol 1997;71:4241-53. [PubMed: 9151811]

Beebe AM, Dua N, Faith TG, Moore PF, Pedersen NC, Dandekar S. Primary stage of feline immunodeficiency virus infection: viral dissemination and cellular targets. J Virol 1994;68:3080-91. [PubMed: 8151773]

Bouhamdan M, Benichou S, Rey F, Navarro JM, Agostini I, Spire B, Camonis J, Slupphaug G, Vigne R, Benarous R, Spire J. Human immunodeficiency virus type $1 \mathrm{Vpr}$ protein binds to the uracil DNA glycosylase DNA repair enzyme. J Virol 1996;70:697-704. [PubMed: 8551605]

Brik A, Alexandratos J, Lin YC, Elder JH, Olson AJ, Wlodawer A, Goodsell DS, Wong CH. 1,2,3-triazole as a peptide surrogate in the rapid synthesis of HIV-1 protease inhibitors. Chembiochem 2005;6:11679. [PubMed: 15934050] 
Brown WC, Bissey L, Logan KS, Pedersen NC, Elder JH, Collisson EW. Feline immunodeficiency virus infects both CD4+ and CD8+ T lymphocytes. J Virol 1991;65:3359-64. [PubMed: 1709703]

Brunner D, Pedersen NC. Infection of peritoneal macrophages in vitro and in vivo with feline immunodeficiency virus. J Virol 1989;63:5483-8. [PubMed: 2479773]

Callanan, JJ.; Racz, P.; Thompson, H.; Jarrett, O. Morphologic characterization of the lymph node changes in feline immunodeficiency virus infection as an animal model of AIDS. S. Karger, Basel; Switzerland: 1993.

Chatterji U, de Parseval A, Elder JH. Feline immunodeficiency virus OrfA is distinct from other lentivirus transactivators. J Virol 2002;76:9624-34. [PubMed: 12208941]

Chen B, Vogan EM, Gong H, Skehel JJ, Wiley DC. Structure of an unliganded simian immunodeficiency virus gp120 core. Nature 2005;433:834-41. [PubMed: 15729334]

Cohen OJ, Fauci AS. N Engl J Med 1998;339(5):341-343. [PubMed: 9682050]

Collier AC, Coombs RW, Schoenfeld DA, Bassett RL, Timpone J, Baruch A, Jones M, Facey K, Whitacre C, McAuliffe VJ, Friedman HM, Merigan TC, Reichman RC, Hooper C, Corey L. N Engl J Med 1996;334(16):1011-1017. [PubMed: 8598838]

Condra JH, Schleif WA, Blahy OM, Gabryelski LJ, Graham DJ, Quintero JC, Rhodes A, Robbins HL, Roth E, Shivaprakash M. Nature 1995;374(6522):569-571. [PubMed: 7700387]

Conticello SG, Harris RS, Neuberger MS. The Vif protein of HIV triggers degradation of the human antiretroviral DNA deaminase APOBEC3G. Curr Biol 2003;13:2009-13. [PubMed: 14614829]

Delwart EL, Gordon CJ. Tracking changes in HIV-1 envelope quasispecies using DNA heteroduplex analysis. Methods 1997;12:348-54. [PubMed: 9245616]

Demirov DG, Orenstein JM, Freed EO. The late domain of human immunodeficiency virus type 1 p6 promotes virus release in a cell type-dependent manner. J Virol 2002;76:105-17. [PubMed: 11739676]

de Parseval A, Grant CK, Sastry KJ, Elder JH. Sequential CD134- CXCR4 interactions in feline immunodeficiency virus (FIV): soluble CD134 activates FIV Env for CXCR4-dependent entry and reveals a cryptic neutralization epitope. J Virol 2006;80:3088-91. [PubMed: 16501119]

de Parseval A, Bobardt MD, Elder JH, David G, Zolla-Pazner S. A Highly Conserved Arginine in Gp120 Governs HIV-1 Binding to Both CCR5 and Syndecans Via a Sulfated Motif. J Biol Chem 2005;280:39493-504. [PubMed: 16157597]

de Parseval A, Chatterji U, Sun P, Elder JH. Feline immunodeficiency virus targets activated CD4+T cells by using CD134 as a binding receptor. Proc Natl Acad Sci USA 2004;101:13044-9. [PubMed: 15326292]

de Parseval A, Chatterji U, Morris G, Sun P, Olson AJ. Structural mapping of CD134 residues critical for interaction with feline immunodeficiency virus. Nat Struct Mol Biol 2005;12:60-6. [PubMed: 15592478]

de Parseval A, Elder JH. Binding of recombinant feline immunodeficiency virus surface glycoprotein to feline cells: role of CXCR4, cell-surface heparans, and an unidentified non-CXCR4 receptor. J Virol 2001;75:4528-39. [PubMed: 11312323]

de Parseval A, Elder JH. Demonstration that orf2 encodes the feline immunodeficiency virus transactivating (Tat) protein and characterization of a unique gene product with partial rev activity. J Virol 1999;73:608. [PubMed: 9847366]

de Rozieres S, Mathiason CK, Rolston MR, Chatterji U, Hoover EA. Characterization of a highly pathogenic molecular clone of feline immunodeficiency virus clade C. J Virol 2004;78:8971-82. [PubMed: 15308694]

Dunn BM, Gustchina A, Wlodawer A, Kay J. Methods Enzymol 1994;241:254-278. [PubMed: 7854181]

Dunn BM, Pennington MW, Frase DC, Nash K. Biopolymers 1999;51(1):69-77. [PubMed: 10380354]

Elder JH, Lerner DL, Hasselkus-Light CS, Fontenot DJ, Hunter E. Distinct subsets of retroviruses encode dUTPase. J Virol 1992;66:1791-4. [PubMed: 1310783]

Elder JH, Schnolzer M, Hasselkus-Light CS, Henson M, Lerner DA, Phillips TR, Wagaman PC, Kent SB. Identification of proteolytic processing sites within the Gag and Pol polyproteins of feline immunodeficiency virus. J Virol 1993;67:1869-76. [PubMed: 8383214] 
English RV, Nelson P, Johnson CM, Nasisse M, Tompkins WA. Development of clinical disease in cats experimentally infected with feline immunodeficiency virus. J Infect Dis 1994;170:543-52. [PubMed: 8077711]

Erickson J, Neidhart DJ, VanDrie J, Kempf DJ, Wang XC, Norbeck DW, Plattner JJ, Rittenhouse JW, Turon M, Wideburg N. Science 1990;249(4968):527-533. [PubMed: 2200122]

Freed EO. Viral late domains. J Virol 2002;76:4679-87. [PubMed: 11967285]

Garrus JE, von Schwedler UK, Pornillos OW, Morham SG, Zavitz KH. Tsg101 and the vacuolar protein sorting pathway are essential for HIV-1 budding. Cell 2001;107:55-65. [PubMed: 11595185]

Gemeniano MC, Sawai ET, Sparger EE. Feline immunodeficiency virus Orf-A localizes to the nucleus and induces cell cycle arrest. Virology 2004;325:167-74. [PubMed: 15246256]

Gemeniano MC, Sawai ET, Leutenegger CM, Sparger EE. Feline immunodeficiency virus ORF-A is required for virus particle formation and virus infectivity. J Virol 2003;77:8819-30. [PubMed: 12885901]

Gross I, Hohenberg H, Wilk T, Wiegers K, Grattinger M, Muller B, Fuller S, Krausslich HG. EMBO J 2000;19(1):103-113. [PubMed: 10619849]

Gulick RM, Mellors JW, Havlir D, Eron JJ, Gonzalez C, McMahon D, Richman DD, Valentine FT, Jonas L, Meibohm A, Emini EA, Chodakewitz JA. N Engl J Med 1997;337(11):734-739. [PubMed: 9287228]

He M, Gani M, Livnah O, Stura EA, Beale D. Sequence, specificity and crystallization of an oestrone-3glucuronide antibody (3910). Immunology 1997;90:632-9. [PubMed: 9176119]

Hurtrel B, Chakrabarti L, Hurtrel M, Bach JM, Ganiere JP. Early events in lymph nodes during infection with SIV and FIV. Res Virol 1994;145:221-7. [PubMed: 7800949]

Jacobsen H, Hanggi M, Ott M, Duncan IB, Owen S, Andreoni M, Vella S, Mous J. J Infect Dis 1996;173 (6):1379-1387. [PubMed: 8648209]

Johnson VA, Brun-Vezinet F, Clotet B, Conway B, Kuritzkes DR, Pillay D, Schapiro JM, Telenti A, Richman DD. Top HIV Med 2005;13(4):125-131. [PubMed: 16304457]

Joshi A, Garg H, Tompkins MB, Tompkins WA. Preferential feline immunodeficiency virus (FIV) infection of CD4+ CD25+ T-regulatory cells correlates both with surface expression of CXCR4 and activation of FIV long terminal repeat binding cellular transcriptional factors. J Virol 2005;79:496576. [PubMed: 15795282]

Katz RA, Skalka AM. Annu. Rev Biochem 1994;63:133-173.

Kirk O, Katzenstein TL, Gerstoft J, Mathiesen L, Nielsen H, Pedersen C, Lundgren JD. AIDS 1999;13 (1):F9-16. [PubMed: 10207539]

Kozal M. AIDS Patient Care STDS 2004;18(4):199-208. [PubMed: 15142350]

Kutilek VD, Sheeter DA, Elder JH, Torbett BE. Curr Drug Targets Infect Disord 2003;3(4):295-309. [PubMed: 14754431]

Kwong PD, Doyle ML, Casper DJ, Cicala C, Leavitt SA. HIV- 1 evades antibody-mediated neutralization through conformational masking of receptor- binding sites. Nature 2002;420:678-82. [PubMed: 12478295]

Labrijn AF, Poignard P, Raja A, Zwick MB, Delgado K. Access of antibody molecules to the conserved coreceptor binding site on glycoprotein gp120 is sterically restricted on primary human immunodeficiency virus type 1. J Virol 2003;77:10557-65. [PubMed: 12970440]

Laco GS, Fitzgerald MC, Morris GM, Olson AJ, Kent SB, Elder JH. J Virol 1997;71(7):5505-5511. [PubMed: 9188624]

Laco GS, Schalk-Hihi C, Lubkowski J, Morris G, Zdanov A. Crystal structures of the inactive D30N mutant of feline immunodeficiency virus protease complexed with a substrate and an inhibitor. Biochemistry 1997;36:10696-708. [PubMed: 9271500]

Lafrado L, Podell M, Krakowka S, Hayes K, Hanlon M, Hanlon M, Mathes LE. FIV: a model for retrovirus-induced pathogenesis. AIDS Res Rev 1993;3:115-150.

Lawrence J, Schapiro J, Winters M, Montoya J, Zolopa A, Pesano R, Efron B, Winslow D, Merigan TC. J Infect Dis 1999;179(6):1356-1364. [PubMed: 10228055]

Lee T, Laco GS, Torbett BE, Fox HS, Lerner DL. Analysis of the S3 and S3' subsite specificities of feline immunodeficiency virus (FIV) protease: Development of a broad-based protease inhibitor efficacious 
against FIV, SIV, and HIV in vitro and ex vivo. Proc Natl Acad Sci USA 1998;95:939-44. [PubMed: 9448264]

Lee T, Le VD, Lim D, Lin YC, Morris G, Wong AL, Olson AJ, Elder JH, Wong CH. J. Am Chem Soc 1999;121:1145-1155.

Lerner DL, Wagaman PC, Phillips TR, Prospero-Garcia O, Henriksen SJ. Increased mutation frequency of feline immunodeficiency virus lacking functional deoxyuridine-triphosphatase. Proc Natl Acad Sci USA 1995;92:7480-4. [PubMed: 7638216]

Lin YC, Beck Z, Lee T, Le VD, Morris GM, Olson AJ, Wong CH, Elder JH. Alteration of Substrate Inhibitor Specificity of Feline Immunodeficiency Virus Protease. J Virol 2000;74(10):4710-4720. [PubMed: 10775609]

Lin YC, Beck Z, Morris GM, Olson AJ, Elder JH. Structural Basis for Distinctions between Substrate and Inhibitor Specificities for Feline Immunodeficiency Virus and Human Immunodeficiency Virus Proteases. J Virol 2003;77(12):6589-6600. [PubMed: 12767979]

Lin YC, Brik A, de Parseval A, Tam K, Torbett BE, Wong CH, Elder JH. Altered Gag Polyprotein Cleavage Specificity of Feline Immunodeficiency Virus/Human Immunodeficiency Virus Mutant Proteases as Demonstrated in a Cell-Based Expression System. J Virol 2006;80(16):7832-7843. [PubMed: 16873240]

Lusso P, Earl PL, Sironi F, Santoro F, Ripamonti C. Cryptic nature of a conserved, CD4-inducible V3 loop neutralization epitope in the native envelope glycoprotein oligomer of CCR5-restricted, but not CXCR4-using, primary human immunodeficiency virus type 1 strains. J Virol 2005;79:6957-68. [PubMed: 15890935]

Mangeat B, Turelli P, Caron G, Friedli M, Perrin L. Broad antiretroviral defence by human APOBEC3G through lethal editing of nascent reverse transcripts. Nature 2003;424:99-103. [PubMed: 12808466]

Manrique ML, Rauddi ML, Gonzalez SA, Affranchino JL. Functional domains in the feline immunodeficiency virus nucleocapsid protein. Virology 2004;327:83-92. [PubMed: 15327900]

Mansky LM, Preveral S, Selig L, Benarous R, Benichou S. The interaction of vpr with uracil DNA glycosylase modulates the human immunodeficiency virus type 1 In vivo mutation rate. J Virol 2000;74:7039-47. [PubMed: 10888643]

Marin M, Rose KM, Kozak SL, Kabat D. HIV-1 Vif protein binds the editing enzyme APOBEC3G and induces its degradation. Nat Med 2003;9:1398-403. [PubMed: 14528301]

Martin-Serrano J, Zang T, Bieniasz PD. HIV-1 and Ebola virus encode small peptide motifs that recruit Tsg101 to sites of particle assembly to facilitate egress. Nat Med 2001;7:1313-9. [PubMed: 11726971]

Mehle A, Strack B, Ancuta P, Zhang C, McPike M. Vif overcomes the innate antiviral activity of APOBEC3G by promoting its degradation in the ubiquitin- proteasome pathway. J Biol Chem 2004;279:7792-8. [PubMed: 14672928]

Miller M, Schneider J, Sathyanarayana BK, Toth MV, Marshall GR, Clawson L, Selk L, Kent SB, Wlodawer A. Science 1989;246(4934):1149-1152. [PubMed: 2686029]

Molla A, Korneyeva M, Gao Q, Vasavanonda S, Schipper PJ, Mo HM, Markowitz M, Chernyavskiy T, Niu P, Lyons N, Hsu A, Granneman GR, Ho DD, Boucher CA, Leonard JM, Norbeck DW, Kempf DJ. Nat Med 1996;2(7):760-766. [PubMed: 8673921]

Moore ML, Bryan WM, Fakhoury SA, Magaard VW, Huffman WF, Dayton BD, Meek TD, Hyland L, Dreyer GB, Metcalf BW. Biochem Biophys Res Commun 1989;159(2):420-425. [PubMed: 2649094]

Morikawa S, Bishop DH. Identification and analysis of the gag-pol ribosomal frameshift site of feline immunodeficiency virus. Virology 1992;186:389-97. [PubMed: 1310175]

Moulard M, Phogat SK, Shu Y, Labrijn AF, Xiao X. Broadly cross-reactive HIV-1-neutralizing human monoclonal Fab selected for binding to gp120-CD4-CCR5 complexes. Proc Natl Acad Sci USA 2002;99:6913-8. [PubMed: 11997472]

North TW, North GL, Pedersen NC. Feline immunodeficiency virus, a model for reverse transcriptasetargeted chemotherapy for acquired immune deficiency syndrome. Antimicrob Agents Chemother 1989;33:915-9. [PubMed: 2475068] 
Novotney C, English RV, Housman J, Davidson MG, Nasisse MP. Lymphocyte population changes in cats naturally infected with feline immunodeficiency virus. AIDS 1990;4:1213-8. [PubMed: 1982410]

Obert LA, Hoover EA. Feline immunodeficiency virus clade $\mathrm{C}$ mucosal transmission and disease courses. AIDS Res Hum Retrov 2000;16:677-88.

Olmsted RA, Barnes AK, Yamamoto JK, Hirsch VM, Purcell RH. Molecular cloning of feline immunodeficiency virus. Proc Natl Acad Sci USA 1989;86:2448-52. [PubMed: 2928341]

O'Neil LL, Burkhard MJ, Diehl LJ, Hoover EA. Vertical transmission of feline immunodeficiency virus. Semin Vet Med Surg (Small Anim) 1995;10:266-78. [PubMed: 8820602]

O'Neil LL, Burkhard MJ, Hoover EA. Frequent perinatal transmission of feline immunodeficiency virus by chronically infected cats. J Virol 1996;70:2894-901. [PubMed: 8627764]

Palella FJ Jr, Delaney KM, Moorman AC, Loveless MO, Fuhrer J, Satten GA, Aschman DJ, Holmberg SD. N Engl J Med 1998;338(13):853-860. [PubMed: 9516219]

Pancino G, Castelot S, Sonigo P. Differences in feline immunodeficiency virus host cell range correlate with envelope fusogenic properties. Virology 1995;206:796-806. [PubMed: 7856093]

Pancino G, Fossati I, Chappey C, Castelot S, Hurtrel B. Structure and variations of feline immunodeficiency virus envelope glycoproteins. Virology 1993;192:659-62. [PubMed: 8380668]

Parodi AL, Femenia F, Moraillon A, Crespeau F, Fontaine JJ. Histopathological changes in lymph nodes of cats experimentally infected with the feline immunodeficiency virus (FIV). J Comp Pathol 1994;111:165-74. [PubMed: 7806702]

Pedersen, NC. The Feline Immunodeficiency Virus. In: Levy, JA., editor. The Retroviridae. Plenum Press; NewYork: 1993. p. 181-228.

Pedersen NC, Ho EW, Brown ML, Yamamoto JK. Isolation of a T-lymphotropic virus from domestic cats with an immunodeficiency-like syndrome. Science 1987;235:790-3. [PubMed: 3643650]

Pettit SC, Clemente JC, Jeung JA, Dunn BM, Kaplan AH. J Virol 2005;79(16):10601-607. [PubMed: 16051852]

Pettit SC, Everitt LE, Choudhury S, Dunn BM, Kaplan AH. J Virol 2004;78(16):8477-8485. [PubMed: 15280456]

Pettit SC, Lindquist JN, Kaplan AH, Swanstrom R. Retrovirology 2005;2(1):66. [PubMed: 16262906]

Pettit SC, Moody MD, Wehbie RS, Kaplan AH, Nantermet PV, Klein CA, Swanstrom R. J Virol 1994;68 (12):8017-8027. [PubMed: 7966591]

Pettit SC, Sheng N, Tritch R, Erickson-Viitanen S, Swanstrom R. Adv. Exp Med Biol 1998;436:15-25.

Pettit SC, Simsic J, Loeb DD, Everitt L, Hutchison CAd, Swanstrom R. J Biol Chem 1991;266(22): 14539-14547. [PubMed: 1860860]

Phillips TR, Lamont C, Konings DA, Shacklett BL, Hamson CA. Identification of the Rev transactivation and Rev-responsive elements of feline immunodeficiency virus. J Virol 1992;66:5464-71. [PubMed: 1323707]

Phillips TR, Prospero-Garcia O, Puaoi DL, Lerner DL, Fox HS. Neurological abnormalities associated with feline immunodeficiency virus infection. J Gen Virol 1994;75:979-87. [PubMed: 8176384]

Phillips TR, Prospero-Garcia O, Wheeler DW, Wagaman PC, Lerner DL. Neurologic dysfunctions caused by a molecular clone of Feline Immundeficiency Virus, FIV-PPR. J Neurovirol 1996;2:388-396. [PubMed: 8972420]

Phillips TR, Talbott RL, Lamont C, Muir S, Lovelace K. Comparison of two host cell range variants of feline immunodeficiency virus. J Virol 1990;64:4605-13. [PubMed: 1697907]

Poeschla EM, Looney DJ. CXCR4 is required by a nonprimate lentivirus: heterologous expression of feline immunodeficiency virus in human, rodent, and feline cells. J Virol 1998;72:6858-66. [PubMed: 9658135]

Polgar L, Szeltner Z, Boros I. Biochemistry 1994;33(31):9351-9357. [PubMed: 8049236]

Prasad GS, Stura EA, McRee DE, Laco GS, Hasselkus-Light C. Crystal structure of dUTP pyrophosphatase from feline immunodeficiency virus. Protein Sci 1996;5:2429-37. [PubMed: 8976551] 
Prospero-Garcia O, Herold N, Phillips TR, Elder JH, Bloom FE. Sleep patterns are disturbed in cats infected with feline immunodeficiency virus. Proc Nat Acad Sci USA 1994;91:12947-51. [PubMed: 7809152]

Prospero-Garcia O, Herold N, Waters AK, Phillips TR, Elder JH. Intraventricular administration of a FIV-envelope protein induces sleep architecture changes in rats. Brain Res 1994;659:254-8. [PubMed: 7820670]

Rhee SY, Gonzales MJ, Kantor R, Betts BJ, Ravela J, Shafer RW. Human Immunodeficiency virus reverse transcripts and protease sequence database. Nucleic Acids Res 2003;31(1):298-303. [PubMed: 12520007]

Richman DD, Morton SC, Wrin T, Hellmann N, Berry S, Shapiro MF, Bozzette SA. AIDS 2004;18(10): 1393-1401. [PubMed: 15199315]

Rideout BA, Lowensteine LJ, Hutson CA, Moore PF, Pedersen NC. Characterization of morphologic changes and lymphocyte subset distribution in lymph nodes from cats with naturally acquired feline immunodeficiency virus infection. Vet Pathol 1992;29:391-9. [PubMed: 1413406]

Rogers AB, Hoover EA. Maternal-fetal feline immunodeficiency virus transmission: timing and tissue tropisms. J Infect Dis 1998;178:960-7. [PubMed: 9806022]

Shinazi RF, Larder BA, Mellors JW. Mutations in Retroviral Genes Associated with Drug Resistance. Intl Antiviral News 1993;5:129-142.

Schnolzer M, Rackwitz HR, Gustchina A, Laco GS, Wlodawer A, Elder JH, Kent SB. Virology 1996;224 (1):268-275. [PubMed: 8862421]

Schrofelbauer B, Yu Q, Zeitlin SG, Landau NR. Human immunodeficiency virus type 1 Vpr induces the degradation of the UNG and SMUG uracil-DNA glycosylases. J Virol 2005;79:10978-87. [PubMed: 16103149]

Shacklett BL, Luciw PA. Analysis of the vif gene of feline immunodeficiency virus. Virology 1994;204:860-7. [PubMed: 7941360]

Sheehy AM, Gaddis NC, Malim MH. The antiretroviral enzyme APOBEC3G is degraded by theproteasome in response to HIV-1 Vif. Nat Med 2003;9:1404-7. [PubMed: 14528300]

Shimojima M, Miyazawa T, Ikeda Y, McMonagle EL, Haining H. Use of CD134 as a primary receptor by the feline immunodeficiency virus. Science 2004;303:1192-5. [PubMed: 14976315]

Silva AM, Cachau RE, Sham HL, Erickson JW. J Mol Biol 1996;255(2):321-346. [PubMed: 8551523]

Slee DH, Laslo KL, Elder JH, Ollmann IR, Gustchina A, Kervinen K, Zdanov A, Wlodawer A, Wong CH. J. Am Chem Soc 1995;117:11867-11878.

Sodora DL, Shpaer EG, Kitchell BE, Dow SW, Hoover EA. Identification of three feline immunodeficiency virus (FIV) env gene subtypes and comparison of the FIV and human immunodeficiency virus type 1 evolutionary patterns. J Virol 1994;68:2230-8. [PubMed: 8139008]

Sodora DL, Courcelle J, Brojatsch J, Berson A, Wang YC. Analysis of a feline immunodeficiency virus provirus reveals patterns of gene sequence conservation distinct from human immunodeficiency virus type 1. AIDS Res Hum Retrovir 1995;11:531-3. [PubMed: 7632468]

Sparger EE, Luciw PA, Elder JH, Yamamoto JK, Lowenstine LJ. Feline immunodeficiency virus is a lentivirus associated with an AIDS-like disease in cats. AIDS 1989;3:S43-9. [PubMed: 2558688]

Sparger EE, Shacklett BL, Renshaw-Gegg L, Barry PA, Pedersen NC. Regulation of gene expression directed by the long terminal repeat of the feline immunodeficiency virus. Virology 1992;187:16577. [PubMed: 1310554]

Stanfield RL, Ghiara JB, Ollmann Saphire E, Profy AT, Wilson IA. Recurring conformation of the human immunodeficiency virus type 1 gp120 V3 loop. Virology 2003;315:159-73. [PubMed: 14592768]

Staszewski S, Miller V, Sabin C, Carlebach A, Berger AM, Weidmann E, Helm EB, Hill A, Phillips A. AIDS 1999;13(3):367-373. [PubMed: 10199227]

Steagall WK, Robek MD, Perry ST, Fuller FJ, Payne SL. Incorporation of uracil into viral DNA correlates with reduced replication of EIAV in macrophages. Virology 1995;210:302-13. [PubMed: 7542416]

Stopak K, de Noronha C, Yonemoto W, Greene WC. HIV-1 Vif blocks the antiviral activity of APOBEC3G by impairing both its translation and intracellular stability. Mol Cell 2003;12:591601. [PubMed: 14527406] 
Swain AL, Miller MM, Green J, Rich DH, Schneider J, Kent SB, Wlodawer A. Proc Natl Acad Sci USA 1990;87(22):8805-8809. [PubMed: 2247451]

Swanstrom R, Erona J. Pharmacol Ther 2000;86(2):145-170. [PubMed: 10799712]

Swanstrom, R.; Wills, J. Synthesis, assembly, and processing of viral proteins. In: Coffin, J.; Hughes, S., editors. Retroviruses. Cold Spring Harbor Laboratory Press; NY: 1997. p. 263-334.

Talbott RL, Sparger EE, Lovelace KM, Fitch WM, Pedersen NC. Nucleotide sequence and genomic organization of feline immunodeficiency virus. Proc Natl Acad Sci USA 1989;86:5743-7. [PubMed: 2762293]

Thompson FJ, Elder J, Neil JC. Cis- and trans-regulation of feline immunodeficiency virus: identification of functional binding sites in the long terminal repeat. J Gen Virol 1994;75(Pt 3):545-54. [PubMed: 8126451]

Threadgill DS, Steagall WK, Flaherty MT, Fuller FJ, Perry ST. Characterization of equine infectious anemia virus dUTPase: growth properties of a dUTPase-deficient mutant. J Virol 1993;67:2592600. [PubMed: 8386267]

Tomasselli AG, Heinrikson RL. Methods Enzymol 1994;241:279-301. [PubMed: 7854182]

Tomonaga K, Norimine J, Shin YS, Fukasawa M, Miyazawa T. Identification of a feline immunodeficiency virus gene which is essential for cell-free virus infectivity. J Virol 1992;66:6181-5. [PubMed: 1382146]

Toyosaki T, Miyazawa T, Furuya T, Tomonaga K, Shin YS. Localization of the viral antigen of feline immunodeficiency virus in the lymph nodes of cats at the early stage of infection. Arch Virol 1993;131:335-47. [PubMed: 8102229]

Tozser J, Bagossi P, Weber IT, Louis JM, Copeland TD, Oroszlan S. J Biol Chem 1997;272(27):1680716814. [PubMed: 9201986]

Tozser J, Gustchina A, Weber IT, Blaha I, Wondrak EM, Oroszlan S. FEBS Lett 1991;279(2):356-360. [PubMed: 2001747]

Tozser J, Weber IT, Gustchina A, Blaha I, Copeland TD, Louis JM, Oroszlan S. Biochemistry 1992;31 (20):4793-4800. [PubMed: 1591240]

Vacca JP. Drug Discov 1997;2(7)

Vagin A, Teplyakov A. MOLREP: an Automated Program for Molecular Replacement. J Appl Crystallogr 1997;30:1022-11025.

VerPlank L, Bouamr F, LaGrassa TJ, Agresta B, Kikonyogo A. Tsg101, a homologue of ubiquitinconjugating (E2) enzymes, binds the L domain in HIV type 1 Pr55(Gag). Proc Natl Acad Sci USA 2001;98:7724-9. [PubMed: 11427703]

Vogt V. Curr. Top Microbiol Immunol 1996;214:95-131.

Waters AK, De Parseval AP, Lerner DL, Neil JC, Thompson FJ. Influence of ORF2 on host cell tropism of feline immunodeficiency virus. Virology 1996;215:10-6. [PubMed: 8553580]

Weber IT, Miller M, Jaskolski M, Leis J, Skalka AM, Wlodawer A. Science 1989;243(4893):928-931. [PubMed: 2537531]

Wiegers K, Rutter G, Kottler H, Tessmer U, Hohenberg H, Krausslich HG. J Virol 1998;72(4):28462854. [PubMed: 9525604]

Willett BJ, Adema K, Heveker N, Brelot A, Picard L, Alizon M, Turner JD, Hoxie JA, Peiper S, Neil JC, Hosie MJ. The second extracellular loop of CXCR4 determines its function as a receptor for feline immunodeficiency virus. J Virol 1998;72:6475-81. [PubMed: 9658090]

Willett BJ, Hosie MJ, Callanan JJ, Neil JC, Jarrett O. Infection with feline immunodeficiency virus is followed by the rapid expansion of a CD8+ lymphocyte subset. Immunology 1993;78:1-6. [PubMed: 8094707]

Wlodawer A, Gustchina A, Reshetnikova L, Lubkowski J, Zdanov A, Hui KY, Angleton EL, Farmerie WG, Goodenow MM, Bhatt D. Nat Struct Biol 1995;2(6):480-488. [PubMed: 7664111]

Woo JC, Dean GA, Pedersen NC, Moore PF. Immunopathologic changes in the thymus during the acute stage of experimentally induced feline immunodeficiency virus infection in juvenile cats. J Virol 1997;71:8632-41. [PubMed: 9343221] 
Xiang SH, Farzan M, Si Z, Madani N, Wang L, Rosenberg E, Robinson J, Sodroski J. Functional mimicry of a human immunodeficiency virus type 1 coreceptor by a neutralizing monoclonal antibody. J Virol 2005;79:6068-77. [PubMed: 15857992]

Yamamoto JK, Sparger E, Ho EW, Andersen PR, O’Connor TP, Mandell CP, Lowenstine L, Munn R, Pedersen NC. Pathogenesis of experimentally induced feline immunodeficiency virus infection in cats. Am J Vet Res 1988;49:1246-58. [PubMed: 2459996]

Young B, Johnson S, Bahktiari M, Shugarts D, Young RK, Allen M, Ramey RR 2nd, Kuritzkes DR. J Infect Dis 1998;178(5):1497-1501. [PubMed: 9780274]

Yu X, Yu Y, Liu B, Luo K, Kong W. Induction of APOBEC3G ubiquitination and degradation by an HIV-1 Vif-Cul5-SCF complex. Science 2003;302:1056-60. [PubMed: 14564014]

Zhang YM, Imamichi H, Imamichi T, Lane HC, Falloon J, Vasudevachari MB, Salzman NP. J Virol 1997;71(9):6662-6670. [PubMed: 9261388]

Zhang H, Yang B, Pomerantz RJ, Zhang C, Arunachalam SC, Gao L. The cytidine deaminase CEM15 induces hypermutation in newly synthesized HIV-1 DNA. Nature 2003;424:94-8. [PubMed: 12808465] 

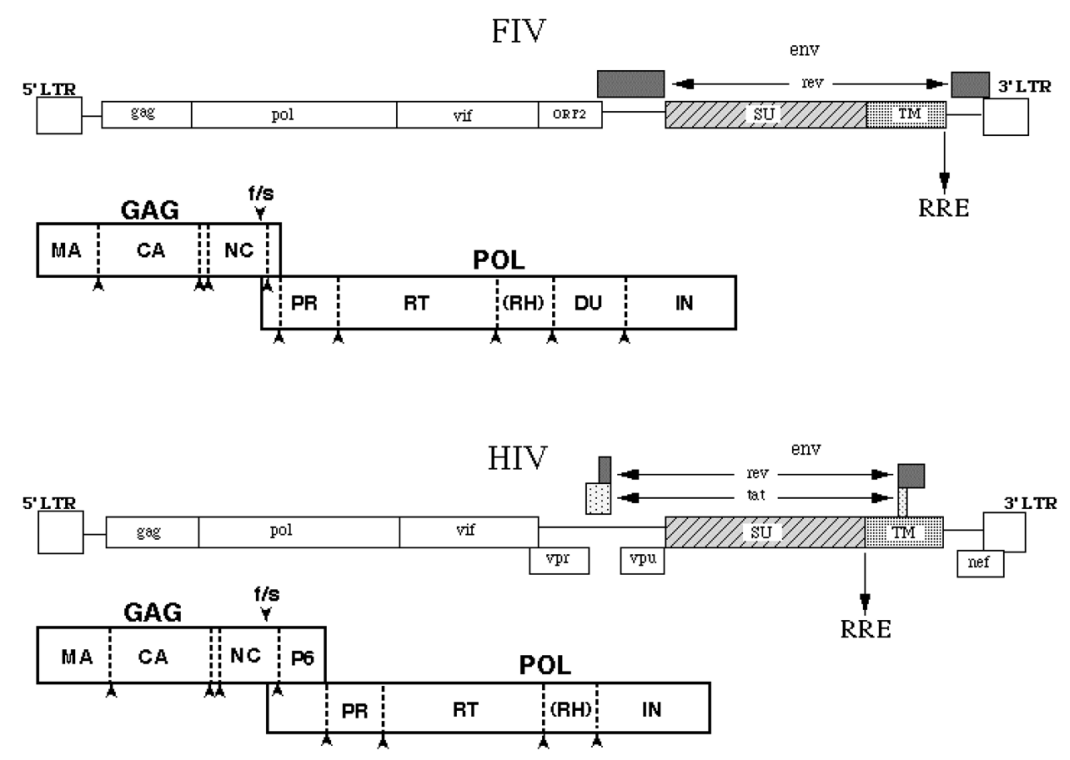

Figure 1.

Comparison of the genomic structures of Feline Immunodeficiency Virus (FIV) and Human Immunodeficiency Virus (HIV). Diagrams are shown for each virus genome as present in the integrated provirus, with organization of each respective Gag-Pol polyprotein shown below. LTR, long terminal repeat; f/s, frameshift; RRE, rev response element; Orf2, open reading frame 2; Vif, viral infectivity factor. 


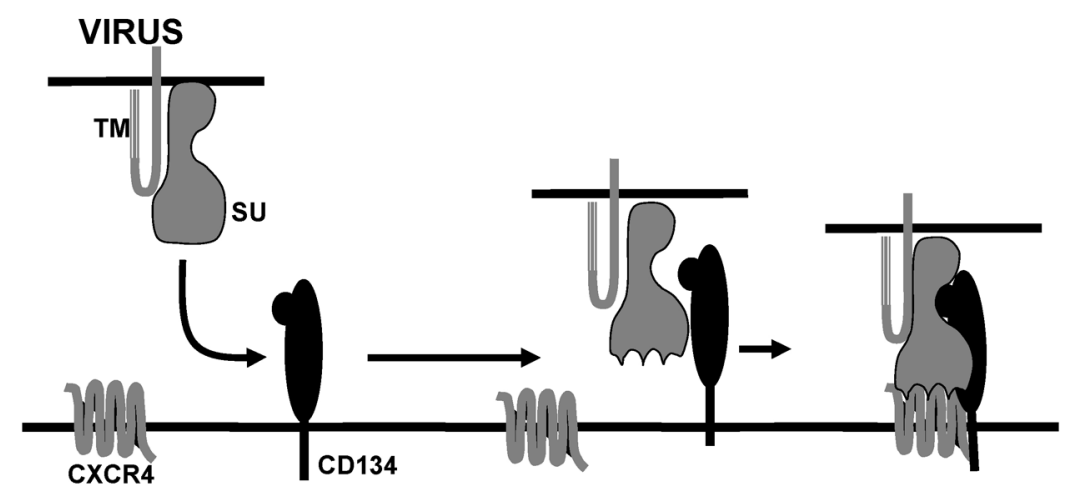

CELL

Figure 2.

Illustration depicting receptor binding events during FIV infection. Primary binding to CD134 causes a conformational change in the FIV surface glycoprotein (SU), which facilitates higher affinity binding to the chemokine receptor, CXCR4. Subsequent fusion events involving the host cell membrane and the viral transmembrane protein, TM, occur to facilitate virus entry (not shown). 


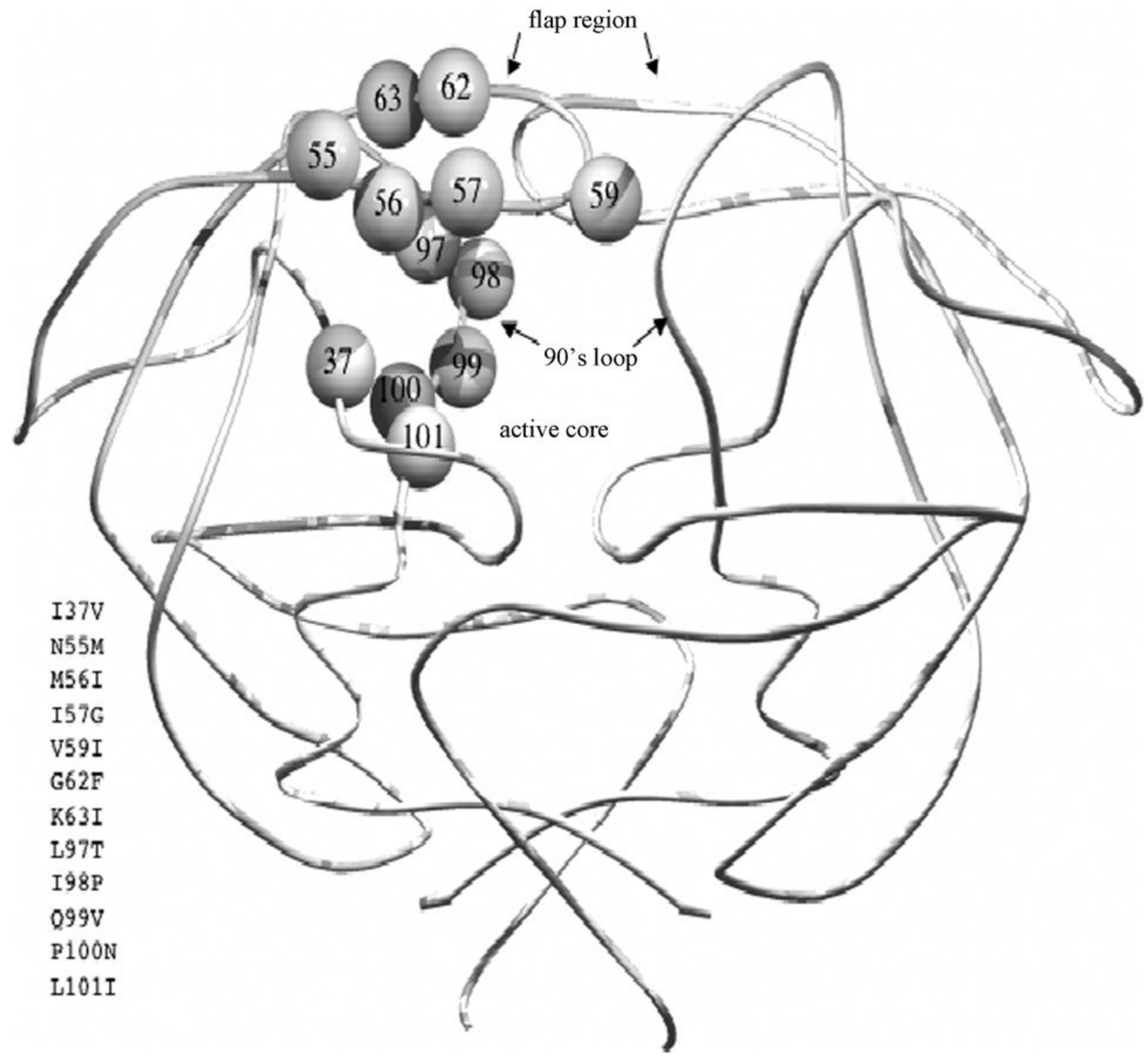

Figure 3.

Structural locations of substituted residues in FIV PR for defining both substrate and inhibitor specificities. Residues substituted in FIV/HIV chimeric PRs are shown on only one chain of the homodimeric FIV PR. Substitutions for equivalent residues of HIV-1 PR (FIV numbering with HIV-1 numbering in superscript) include $137^{32} \mathrm{~V}$ in the active core, $N 55^{46} \mathrm{M}, \mathrm{M} 56^{47} \mathrm{I}$, $\mathrm{I} 57^{48} \mathrm{G}$, V5 $9^{50} \mathrm{I}, \mathrm{G} 62^{53} \mathrm{~F}$, and $\mathrm{K} 63^{54} \mathrm{I}$ in the flap, $\mathrm{L} 97^{80} \mathrm{~T}, \mathrm{I} 98^{81} \mathrm{P}, \mathrm{Q} 99^{82} \mathrm{~V}, \mathrm{P} 100^{83} \mathrm{~N}$, and L101 ${ }^{84}$ I in 90's loop. 